\title{
9. UCZENIE MASZYNOWE W BUDOWIE PORTFELA INWESTYCYJNEGO
}

\author{
(D) Przemysław Grobelny \\ Uniwersytet Ekonomiczny w Poznaniu \\ przemyslaw.grobelny@ue.poznan.pl \\ (D) Tomasz Kaczmarek \\ Uniwersytet Ekonomiczny w Poznaniu \\ tomasz.kaczmarek@phd.ue.poznan.pl \\ (D) Mateusz Piotrowski \\ Uniwersytet Ekonomiczny w Poznaniu \\ mateusz.piotrowski348@gmail.com \\ https://doi.org/10.18559/978-83-8211-083-8/9
}

\section{Machine learning in building investment portfolio}

\begin{abstract}
The chapter describes the characteristics of machine learning methods in their possible application in investment portfolio optimization. With the use of the SWOT analysis, the features of the algorithms responsible for their increasing popularization in the formulation of investment strategies and their limitations in this regard were discussed. The prospects for further development of machine learning were described in the context of the market and technological environment. In addition, based on the review of the research, the possibilities of using machine learning algorithms in managing the investment portfolio and the use of modern research methods, which can be a creative development of the needs and solution to the problems faced by researchers of financial science and financial market practitioners, have been presented.
\end{abstract}

Keywords: machine learning, algorithms, investment portfolio, investment strategy, investment portfolio management.

\subsection{Wstęp}

W ostatnich latach zarówno badacze, jak i praktycy rynku kapitałowego dostrzegli potencjał w stosowaniu uczenia maszynowego (machine learning, ML) do przezwyciężania niedociągnięć tradycyjnych metod w thumaczeniu problemów i przewidywaniu zjawisk w różnych obszarach finansów. Do dziedzin tych zaliczają się między innymi wycena instrumentów finansowych, przewidywanie notowań indeksów akcji, wycena instrumentów pochodnych, wycena nieruchomości, pomiar

Sugerowane cytowanie:

Grobelny, P., Kaczmarek, T. i Piotrowski, M. (2021). Uczenie maszynowe w budowie portfela inwestycyjnego. W: K. Perez (red.), Innowacje finansowe w gospodarce 4.0 (s. 159-178). Poznań: Wydawnictwo Uniwersytetu Ekonomicznego w Poznaniu. https://doi.org/10.18559/978-83-8211-083-8/9 
premii za ryzyko inwestycyjne czy prognoza ryzyka kredytowego w bankowości (Weigand, 2019). W poszczególnych obszarach finansów są stosowane i rozwijane różne podejścia do uczenia maszynowego, które odpowiadają specyficznym potrzebom danej problematyki.

Obszarem finansów o unikatowym zapotrzebowaniu zgłaszanym zarówno przez przedstawicieli świata nauki, jak i praktyków rynkowych jest optymalizacja składu portfela inwestycyjnego. Od czasu sformułowania przez Markowitza (1952) kryteriów optymalizacji portfela inwestycyjnego rozwijane są koncepcje i narzędzia mające na celu poprawianie efektywności inwestowania w ujęciu portfelowym. Uczenie maszynowe dostarcza potężnego instrumentarium przyczyniającego się do rozwiązywania dylematów, które od lat towarzyszą temu zagadnieniu.

W tym rozdziale przedstawiono charakterystykę metod uczenia maszynowego w kontekście możliwości ich aplikacji w obszarze budowy portfela inwestycyjnego. Za pomocą analizy SWOT omówiono cechy algorytmów, które odpowiadają za ich coraz powszechniejsze wykorzystanie w zakresie formułowania strategii inwestycyjnych, ale też ograniczają je w tym zakresie. W kontekście otoczenia rynkowego i technologicznego omówiono perspektywy dalszego rozwoju możliwości aplikacyjnych uczenia maszynowego w obszarze inwestycyjnym. Ponadto zaprezentowano konkluzje z dokonanego przeglądu głównych kierunków badawczych odnoszących się do portfela inwestycyjnego, w których stosowanie metod uczenia maszynowego przyczyniło się do sformułowania nowych teorii, udoskonalenia stosowanych rozwiązań czy wykreowania nieznanych dotąd zastosowań praktycznych.

\subsection{Charakterystyka uczenia maszynowego}

\section{Pojęcie sztucznej inteligencji i uczenia maszynowego}

Sztuczna inteligencja należy obecnie do najszybciej rozwijających się dziedzin technologii na świecie. Sam termin „sztuczna inteligencja” powstał w połowie $\mathrm{XX}$ wieku, lecz na przełomie wieków, wraz z rozwojem technologii, pojęcie to ulegało redefinicji. Mimo że w obecnych czasach człowiek spotyka się ze sztuczną inteligencją praktycznie w każdym aspekcie życia (na przykład przy korzystaniu ze smartfonu), pojęcie to jest wciąż relatywnie mało znane i nie do końca rozumiane. Najczęściej przyjmuje się, że sztuczna inteligencja to gałąź informatyki polegająca na projektowaniu algorytmów w urządzeniach, których funkcjonowanie ma cechy inteligencji, czyli zdolność do adaptacji do nowych warunków, nauki, podejmowania złożonych decyzji oraz abstrakcyjnego myślenia (Géron, 2019).

Pojęcie „uczenia maszynowego” jest węższym, wyspecjalizowanym zagadnieniem wywodzącym się ze sztucznej inteligencji. Również nie jest pojęciem 
nowym - jest używane od końca lat 50. XX wieku. Uczenie maszynowe oznacza zdolność systemów operacyjnych komputerów do uczenia się na podstawie doświadczenia uzyskanego z wcześniej przeprowadzonych działań. Innymi słowy, program udoskonala algorytmy na podstawie nowo przetworzonych danych (Paliński, 2018).

Metody machine learning są najczęściej klasyfikowane według kryterium rodzaju informacji dostarczonych modelowi w toku jego trenowania. Na tym tle wyróżnia się uczenie nadzorowane, nienadzorowane oraz uczenie przez wzmacnianie (Barto i Dietterich, 2004). Uczenie nadzorowane oznacza kontrolę człowieka na początkowym etapie wprowadzania danych uczących się, które łączy się w pary: dana wejściowa (ucząca się) oraz nadzorca. Algorytmy na podstawie danych szacują najbardziej prawdopodobne odpowiedzi oraz wyciągają wnioski z nowo wprowadzonych danych, które są wykorzystywane w przyszłości. Przykładem systemów działających według tego rodzaju schematu są modele klasyfikujące akcje poszczególnych spółek do wcześniej predefiniowanych na podstawie innych instrumentów grup spółek wzrostowych i dywidendowych. Uczenie nienadzorowane jest przeciwieństwem uczenia nadzorowanego i polega na znajdowaniu w zbiorze danych prawidłowych odpowiedzi bez wcześniejszego opisania danych. Dwie główne techniki nauczania nienadzorowanego to analiza skupień i analiza składowych głównych. Uczenie przez wzmacnianie jest całkowicie odmienną techniką, ponieważ nie wykorzystuje zbiorów danych, tylko otoczenie, z którego dane są zbierane automatycznie. Za pomocą określonej polityki algorytm uczenia przez wzmacnianie zbiera dane $\mathrm{z}$ otoczenia do bufora oraz udoskonala zadany proces do chwili osiągnięcia zamierzonego celu (Géron, 2019).

\section{Obszary zastosowania uczenia maszynowego w finansach}

Choć zagadnienia związane z uczeniem maszynowym są rozwijane już od końca lat 50. XX wieku, to dynamika postępu ich udoskonalania przyspieszyła istotnie w ostatnich kilkunastu latach. Największe ograniczenie w rozwoju nauczania maszynowego stanowiły trudność i koszt gromadzenia danych wykorzystywanych przez algorytmy. Praktycznie do końca XX wieku proste algorytmy uczące były wykorzystywane wyłącznie w informatyce. Dopiero wraz z postępem technologii otworzyła się możliwość zastosowania bardziej skomplikowanych algorytmów uczących w programowaniu maszyn wykorzystywanych na przykład w przemyśle (Weigand, 2019). Dziś machine learning jest już wykorzystywany w praktycznie każdej gałęzi gospodarki, w tym również w finansach, między innymi w takich obszarach, jak: wycena akcji, przewidywanie notowań indeksów akcji, wycena instrumentów pochodnych, wycena nieruchomości, pomiar premii za ryzyko inwestycyjne czy prognoza ryzyka kredytowego w bankowości (Weigand, 2019). Wśród dodatkowych obszarów zastosowań już dzisiaj praktykowanych wskazać można na predykcję niewypłacalności spółki, dobór strategii inwestycyjnej, 
klasyfikację funduszy inwestycyjnych, ocenę kondycji finansowej przedsiębiorstw, przeciwdziałanie praniu pieniędzy i finansowaniu terroryzmu czy robodoradztwo.

W zakresie predykcji upadłości na podstawie wyliczonych wskaźników finansowych i przy wykorzystaniu sieci neuronowych lub drzewa klasyfikacyjnego weryfikowane jest zagrożenie upadłości jednostki. Obecnie trafność prognoz oszacowanych dzięki uczeniu maszynowemu jest jeszcze na umiarkowanym poziomie i wynosi około $60 \%$ (Paliński, 2018). Podobny scenariusz postępowania występuje w przypadku oceny sytuacji finansowej firmy za pomocą metod ML.

W obecnych czasach, dzięki rozwojowi technologii, wprowadzanie do obrotu pieniędzy pochodzących z przestępstw stało się i łatwiejsze, i trudniejsze do wykrycia. W odpowiedzi na to zagrożenie instytucje państwowe opracowują ramy regulacyjne anti-money laundering (AML), które mają zastosowanie na rynku finansowym. Powszechną praktyką stało się używanie przez instytucje finansowe (na przykład banki, firmy inwestycyjne) algorytmów, które same wykrywają transakcje mogące mieć znamiona przestępstwa i starają się je blokować.

Usługi doradców finansowych w zakresie inwestowania zyskały w ostatnich dekadach znaczną popularność przekładającą się na wysokie zainteresowanie inwestorów. Jednak za pośrednictwem rozwoju technologii w finansach (fin-tech) zmieniły się uwarunkowania świadczenia tego rodzaju usług, gdyż inwestorzy posiadają coraz szerszy dostęp do kluczowych informacji oraz aplikacji umożliwiających im podejmowanie decyzji inwestycyjnych bez konieczności angażowania doradcy. Robo-advisory (robodoradztwo) to stosunkowo nowe pojęcie, używane od 2008 roku (Snihovyi, Kobets i Ivanov, 2019). Oznacza automatyczne doradztwo finansowe, które staje się coraz bardziej popularne zwłaszcza wśród młodych osób i mieści się w pojęciu gospodarki 4.0, czyli „czwartej rewolucji przemysłowej" (Waliszewski, 2020).

Usługi realizowane w ramach modelu robo-advisory mogą znajdować zastosowanie w szczególności w zarządzaniu portfelem inwestycyjnym i osiąganiu dochodu pasywnego. Model stosowany do zarządzania inwestycjami może być projektowany zgdnie z systemem algorytmów wykorzystujących dane o celach i ryzyku, jakie jest skłonny ponieść dany inwestor. Algorytmy mogą między innymi służyć oszacowaniu, jaką kwotę dana jednostka powinna inwestować w określone instrumenty finansowe, by w założonym czasie osiągnąć przewidziane cele (Snihovyi i in., 2019).

Machine learning może stać się kluczowym ogniwem w robo-advisory. Dzięki wykorzystaniu zaawansowanych algorytmów uczących się inwestorzy mogą uzyskać szerszy dostęp do usług robodoradztwa. Ciekawą perspektywą wydaje się istnienie możliwości zdefiniowania cech charakteru danej osoby w kontekście optymalnej strategii inwestowania. Algorytmy na podstawie wprowadzonych danych pochodzących z ankiety mogą opracowywać strategie inwestowania dla danego profilu inwestora, na przykład pod względem skłonności do ryzyka czy 
posiadanej wiedzy dotyczącej instrumentów finansowych. Z kolei po wprowadzeniu danych odnośnie do danego instrumentu finansowego możliwe staje się oszacowanie przyszłej stopy zwrotu, ryzyka czy okresu zwrotu inwestycji. Algorytm uczący się może dobierać odpowiednie instrumenty finansowe dla danego typu inwestora w celu zapewnienia mu optymalnego zysku przy akceptowalnym poziomie ryzyka. W ten sposób za pośrednictwem uczenia maszynowego można dla każdej osoby opracować strategię inwestycyjną, która zapewni optymalne zyski, nawet przy znikomej wiedzy o rynkach kapitałowych danej osoby (Snihovyi i in., 2019).

Robodoradztwo wykorzystujące uczenie maszynowe stanowi perspektywiczną gałąź rewolucji FinTech i coraz więcej firm zaczyna sięgać po rozwiązania z tego zakresu. Dzięki uczeniu maszynowemu inwestowanie może się stawać bardziej przystępne dla osób spoza finansów i pozwalać na uzyskiwanie dodatkowych zysków dla takich inwestorów. Algorytmy machine learning mają także zdolność ograniczania ryzyka poniesienia gwałtownej straty (o tym szerzej w ostatniej części niniejszego rozdziału), co również może stanowić zachętę dla początkujących inwestorów (Waliszewski, 2020).

Podsumowując, w machine learning kluczowy jest dobór odpowiednich algorytmów do konkretnego problemu. Wybierając optymalny algorytm, należy wziąć pod uwagę: problemy klasyfikacyjne, problemy kategoryzacyjne (grupowania) oraz problemy regresyjne. Zagadnienie klasyfikacji pojawia się na przykład przy ocenie zdolności kredytowej i polega na stwierdzeniu, czy dana jednostka starająca się o kredyt będzie rzetelnym płatnikiem. Grupowanie polega na dzieleniu danych wejściowych na odpowiednie podgrupy - na przykład w kontekście oceny, czy akcje danej spółki noszą znamiona inwestycji dochodowej, czy wzrostowej. Natomiast zagadnienia regresyjne mają odpowiadać na pytania o powiązania, jakie występują między zmiennymi zależnymi i niezależnymi.

\subsection{Analiza SWOT stosowania uczenia maszynowego w procesie budowy portfela inwestycyjnego}

W tej części rozdziału zaprezentowano wnioski z przeprowadzonej analizy SWOT stosowania uczenia maszynowego w procesie budowy portfela inwestycyjnego, w ramach której zostały zidentyfikowane mocne i słabe strony analizowanych metod, jak i szanse i zagrożenia płynące $\mathrm{z}$ uwarunkowań otoczenia, w ramach którego są rozwijane.

\section{Mocne strony}

Głównym celem wykorzystania uczenia maszynowego w procesie konstrukcji portfela inwestycyjnego jest poprawa relacji pomiędzy stopą zwrotu a ryzykiem 
inwestycyjnym. Uczenie maszynowe jest doskonałym narzędziem prognostycznym. W przeciwieństwie do większości metod ekonometrycznych jest ono dedykowane do prognozowania przyszłych wartości zmiennych objaśnianych, a nie do badania relacji pomiędzy zmiennymi objaśniającymi oraz zmienną objaśnianą. Ta różnica definiuje większość elementów analizy SWOT względem tradycyjnych metod ekonometrycznych.

Pierwszą i najprawdopodobniej najważniejszą mocną stroną uczenia maszynowego jest zdolność do prognozowania zmiennych objaśnianych na podstawie dużej liczby niejednorodnych danych wejściowych. Najskuteczniejszą metodą, która może służyć do pracy nad tego typu zbiorem danych, są głębokie sieci neuronowe. Gu, Kelly i Xiu (2020) demonstrują możliwość budowy wysoce efektywnych portfeli inwestycyjnych na podstawie kilkuset zmiennych objaśniających z wykorzystaniem 30 tysięcy spółek. Wykorzystane przez nich dane wejściowe obejmują informacje rynkowe (na przykład historyczne stopy zwrotu z akcji czy wolumeny obrotu), dane finansowe (na przykład zyskowność spółek bądź ich tempo wzrostu) oraz dane makroekonomiczne mające wpływ na zróżnicowanie stóp zwrotu akcji (Welch i Goyal, 2007). W innych badaniach sieci neuronowe zostały z powodzeniem wykorzystane do odczytywania sentymentu rynkowego na podstawie analizy tekstu (Groth i Muntermann, 2011) czy nawet analizy obrazu (Obaid i Pukthuanthong, 2018). Umiejętność wyciągania wniosków ze złożonych danych wejściowych oferuje możliwość analizy ogromu informacji, który jest dostępny dla inwestorów giełdowych, a jednocześnie oferuje narzędzie wspierające inwestorów w budowie portfeli charakteryzujących się lepszą relacją pomiędzy ryzkiem a dochodem w porównaniu do inwestycji pasywnych.

Drugą ważną cechą metod uczenia maszynowego jest ich zdolność do wychwytywania nieliniowych relacji pomiędzy wieloma zmiennymi objaśniającymi. W ramach swoistego apelu kierowanego do badaczy rynkowych Cochrane (2011) wskazał, że tradycyjne metody analizy danych pomijają złożoności relacji pomiędzy determinantami zróżnicowania stóp zwrotu z akcji. Tym samym zainicjował szereg badań ukierunkowanych na zdefiniowanie nowych narzędzi lepiej dostosowanych do analizy tak złożonej struktury danych. Odpowiedzią okazały się metody uczenia maszynowego uwzględniające szereg nieliniowych zależności. Cecha ta jest użyteczna z perspektywy wielu zadań prognostycznych obejmujących budowę portfela inwestycyjnego, na przykład analizy zróżnicowania przekroju stóp zwrotu akcji (Freyberger, Neuhierl i Weber, 2020), wieloczynnikowej prognozy szeregów czasowych (Kaczmarek, Bedowska-Sojka, Grobelny i Perez, 2021) czy optymalizacji portfela inwestycyjnego (López de Prado, 2016).

Kolejna mocna strona metod uczenia maszynowego w kontekście budowy portfela inwestycyjnego dotyczy jednej z jej odmian - uczenia przez wzmacnianie. Metoda ta pozwala wytrenować strategię inwestycyjną zoptymalizowaną pod 
kątem potrzeb inwestora oraz specyficznych uwarunkowań rynkowych (takich jak na przykład płynność danego rynku czy poziom kosztów transakcyjnych). $\mathrm{W}$ procesie tysięcy zrealizowanych symulacji inwestycyjnych algorytm wzmacnia wzorce działania, które zostaną mu przedstawione w formie funkcji celu (Sutton i Barto, 1998). Cecha ta oferuje nadzwyczajną elastyczność w zakresie definiowania parametrów tworzonej strategii inwestycyjnej. W tym kontekście funkcja celu może obejmować nie tylko miary ryzyka oparte na dystrybucji stóp zwrotu na koniec okresu pomiaru (na przykład odchylenie standardowe leżące u podstawy wskaźnika Sharpe'a), ale również inne miary zależne od całej ścieżki realizowanych inwestycji (na przykład maksymalne obsunięcie kapitału wykorzystywane do kalkulacji wskaźnika Calmara) (Möller, 2018). Tym samym algorytm może „wyuczyć" się strategii, która będzie dostarczać zdefiniowany przez inwestora maksymalny poziom obsunięcia kapitału w trakcie całego okresu realizowanej inwestycji. O wysokiej użyteczności uczenia przez wzmacnianie w kontekście budowy portfela inwestycyjnego świadczy dodatkowo możliwość zdefiniowania parametrów transakcyjnych, które są uwzględnione w procesie trenowania modelu. Zatem algorytm może „uczyć się” podejmowania decyzji inwestycyjnych w środowisku zbliżonym do rzeczywistych warunków rynkowych. W efekcie strategia inwestycyjna „wyuczona” na środowisku o wysokich kosztach transakcyjnych ma niższą skłonność do dokonywania zmian w składzie portfela niż strategia oparta na wysokich kosztach. Analogiczny mechanizm trenowania modelu może zostać wykorzystany również do innych cech charakteryzujących dany rynek, w tym na przykład płynności notowanych spółek (Fischer, 2018).

Wysokie zdolności predykcyjne oraz szerokie możliwości wykorzystywania metod uczenia maszynowego w ramach konstrukcji portfela inwestycyjnego stanowią o ostatniej ich mocnej stronie, na którą trzeba zwrócić uwagę. Jest nią możliwość dostarczenia narzędzia do tworzenia strategii inwestycyjnych skuteczniejszych od inwestycji pasywnych. Obecnie większość praktyków rynkowych wciąż opiera się na analizie fundamentalnej, w której grono profesjonalistów rynkowych starannie dobiera spółki do portfela. Takie podejście jest kosztowne i niestety często mało efektywne. Niska skuteczność inwestycji aktywnych wywołała niebywałą falę wzrostu w obszarze inwestycji pasywnych, gdzie inwestorzy, stawiając na niskie koszty zarządzania, godzą się na wyniki inwestycyjne zbliżone to indeksów giełdowych. Największa popularność inwestycji pasywnych występuje wśród inwestorów masowych, których nie stać na opłacenie wybitnego zarządzającego. Niestety, sytuacja ta przyspiesza narastanie luki majątkowej, gdyż najbogatsi osiągają stopy zwroty wyższe od osób mniej majętnych. Sztuczna inteligencja oraz idąca wraz z nią automatyzacja procesów inwestycyjnych może zatrzymać ten proces. Strategie inwestycyjne oparte na uczeniu maszynowym mogą być zarówno tanie, jak i skuteczne. 


\section{Słabe strony}

Jednym z kluczowych wyzwań, przed którym stoi projektant strategii inwestycyjnej opartej na uczeniu maszynowym, jest dobór danych, które zostaną wykorzystane do „wyuczenia” modelu. Algorytm powinien „wyuczyć się” różnych stanów rynku tak, aby przygotowywać prognozy na podstawie nieznanych warunków otoczenia. W tym kontekście istotnym problem związanym z prognozowaniem zachowania się kursów giełdowych są zmiany paradygmatów rynkowych, gdzie relacje, do których przyzwyczailiśmy się w ostatnich latach, tracą na znaczeniu. Nowe wyzwania dotyczą również nieobserwowanych wcześniej zjawisk rynkowych. Na przykład pandemia COVID-19 czy kryzys związany z upadkiem Lehman Brothers były wydarzeniami bez precedensu. Opierając się na danych historycznych, algorytmy uczenia maszynowego nie mogły „wyuczyć się”, jak tworzyć prawidłowe prognozy w takich warunkach rynkowych. Racjonalnym podejściem do budowania zdolności prognostycznej uczenia maszynowego powinno być maksymalne wydłużanie historii danych wejściowych. Niemniej kierunek ten wiąże się z licznymi wyzwaniami.

Dylemat dotyczy zarówno cech, które zostaną wybrane do wytrenowania modelu, jak i długości wykorzystanych szeregów czasowych. Problem ten wzrasta, jeśli długość poszczególnych szeregów czasowych wykorzystanych w analizie jest zróżnicowana. Często jedne cechy mogą mieć kilkukrotnie krótszą historię niż pozostałe, co przy tradycyjnym podejściu do analizy danych skutkuje koniecznością podjęcia wyboru w zakresie eliminacji zmiennych o zbyt krótkiej historii lub wyrównania długości szeregów czasowych poprzez zmniejszenie liczby wykorzystanych obserwacji do poziomu odpowiadającego najkrótszej z uwzględnianych zmiennych. Zatem niezależnie od podjętej decyzji zakres danych wejściowych może ulec znaczącemu skróceniu. Istnieją pewne metody pozwalające częściowo rozwiązać ten problem, jednak nie są one doskonałe. Można do nich zaliczyć na przykład symulację historycznych szeregów czy „wyuczenie” kilku modeli bazujących na różnej długości danych wejściowych i porównywanie ich wyników. Problem ten pozostaje jednak kluczowym wyzwaniem, przed którym stoi projektant strategii inwestycyjnej wykorzystującej uczenie maszynowe.

Innym wyzwaniem związanym $z$ algorytmami opartymi na sztucznej inteligencji jest ryzyko przetrenowania oraz związana z nim problematyka doboru hiperparametrów. Istnieją liczne techniki służące do ograniczenia tego ryzyka, na przykład podział bazy danych na zbiór treningowy, walidacyjny oraz testowy, regularyzacja funkcji celu, wczesne zatrzymanie procesu uczenia czy wykorzystanie mechanizmu porzucania (Gu i in., 2020). Poziom wrażliwości poszczególnych algorytmów na przetrenowanie jest zróżnicowany, niemniej problem ten występuje niezależnie od wybranej metody. Kluczową linią obrony przed 
przetrenowaniem jest analiza wyników strategii inwestycyjnej w ujęciu ,poza próbą" (out-of-sample), gdzie ocena modelu następuje na podstawie prognoz powstałych z wykorzystaniem zmiennych objaśniających nieużytych do jego trenowania. Jednak niezależnie od zastosowanych metod obronnych problem przetrenowania rodzi ryzyko uzyskania modelu dopasowanego z punktu widzenia statystyki w wysokim stopniu do danych uczących, jednak pozbawionego ekonomicznych fundamentów i opartego w znacznym stopniu na przypadkowości. Należy mieć świadomość tego ryzyka przy konstruowaniu rozwiązań opartych na uczeniu maszynowym.

Kolejnym wyzwaniem związanym z uczeniem maszynowym jest jego stochastyczna natura. Wagi poszczególnych prób treningowych są inicjowane w sposób losowy, co owocuje odmiennymi wynikami końcowymi wyuczonych modeli. Na ogół prognozy zbudowane na podstawie kolejnych prób treningowych różnią się. Poziom zróżnicowania jest zależny od wielu czynników, w tym od wykorzystanej metody uczenia maszynowego, odpowiedniego poziomu dotrenowania modelu czy jakości wykorzystanych danych wejściowych (Koller i Fratkina, 1998; Yates i Goodman, 2014). Niemniej i tym razem, niezależnie od podjętych działań obronnych, zjawisko i tak występuje i osoba odpowiedzialna za budowę systemu powinna to uwzględnić podczas oceny symulowanych wyników historycznych. Co więcej, dane finansowe charakteryzują się wysokim poziomem szumu informacyjnego (de Prado, 2018).

Do słabych stron uczenia maszynowego należy zaliczyć również potrzebę budowy obszernych baz danych, które mogą służyć do ,wyuczenia” modeli. Metody te ,uczą się” metodą prób i błędów, dlatego dopiero wysoka liczba przeprowadzonych eksperymentów pozwala im na osiągnięcie wysokiej skuteczności prognostycznej. Niestety, dostęp do obszernych baz danych finansowych jest kosztowny, co sprawia, że stworzenie odpowiednego źródła informacji do wytrenowania modelu jest trudne. Jednocześnie wykorzystanie źródeł informacji o niskiej jakości skutkuje istotnym pogorszeniem skuteczności modelu. Każda osoba podejmująca się wyzwania projektowania strategii opartych na uczeniu maszynowym powinna być świadoma ważnego zwrotu związanego z tą tematyką - garbage in, garbage out, co w tłumaczeniu oznacza śmieci na wejściu śmieci na wyjściu.

Wreszcie na koniec warto jeszcze wspomnieć o dwóch istotnych problemach związanych z wykorzystywaniem uczenia maszynowego do budowy portfeli inwestycyjnych. Po pierwsze, trenowanie wybranych modeli wymaga potężnych mocy obliczeniowych. Uwaga ta dotyczy zwłaszcza głębokich sieci neuronowych, których wytrenowanie na dużych zbiorach danych jest niemal niemożliwe na obecnych komputerach przenośnych. Po drugie, wyniki generowane przez dużą część modeli uczenia maszynowego są trudne do zinterpretowania. Problem ten dotyka szczególnie osób rozpoczynających swoją przygodę z trenowaniem modeli, które 
całą energię wkładają w prawidłowe wyuczenie modeli. Tymczasem możliwość interpretacji wyników jest bardzo ważna. Bez niej inwestor traci kontrolę nad decyzjami podejmowanymi przez zaprojektowaną przez niego strategię inwestycyjną. Obecnie są prowadzone liczne badania naukowe ukierunkowane na budowę narzędzi służących do uzyskania zadowalającego poziomu możliwości interpretacji wyników generowanych przez sztuczną inteligencję ${ }^{1}$ (Li i in., 2020).

\section{Szanse}

Dotychczasowe osiągnięcia związane ze stosowaniem uczenia maszynowego w finansach wskazują na optymistyczne perspektywy zarówno dalszego rozwoju w kierunkach wyznaczonych przez dotychczasowe obszary aplikacji praktycznych i badań teoretycznych (opisanych w kolejnej sekcji niniejszego rozdziału), jak i wdrażania algorytmów do kolejnych, zupełnie nowych obszarów związanych z zarządzaniem kapitałem. Na wysokie prawdopodobieństwo materializacji tego scenariusza wskazuje szereg korzystnych uwarunkowań otoczenia mogących wspierać technologie oparte na uczeniu maszynowym.

Do renesansu zastosowań technik uczenia maszynowego w nauce przyczyniły się w dominującej mierze czynniki związane z rozwojem technologicznym, wśród których wymienić można gwałtowny przyrost mocy obliczeniowych, niskie koszty przechowywania danych, dostępność big data, a także szeroką gamę bezpłatnego oprogramowania do przetwarzania danych typu open source (Weigand, 2019). Przewiduje się, że we wskazanych obszarach będzie następować dalszy rozwój.

W zakresie mocy obliczeniowych wzrost w ostatnich latach wynikał między innymi z szerszego stosowania procesorów graficznych. Karty graficzne znalazły zastosowanie nie tylko na gruncie wydobywania kryptowalut, lecz również w obszarze głębokiego uczenia i sztucznej inteligencji (Schlegel, 2015). Algorytmy głębokiego uczenia zostały zaadaptowane w celu wykorzystania podejścia przyśpieszanego przez karty graficzne, co pozwoliło na uzyskanie znacznego wzrostu wydajności i wprowadzenie szkolenia algorytmu w zakresie kilku rzeczywistych problemów. Kontynuacja wzrostu dostępu projektantów systemów opartych na sztucznej inteligencji do mocy obliczeniowych w najbliższej perspektywie może

${ }^{1}$ Na przykład Greenwell, Boehmke i Mccarthy (2018) zaproponowali ustandaryzowane podejście oparte na modelu mające na celu mierzenie relatywnej ważności poszczególnych predyktorów w modelach nadzorowanego uczenia maszynowego. Molnar (2020) usystematyzował istniejące podejścia do interpretacji wyników uzyskiwanych za pomocą algorytmów machine learning, uwzględniających oszacowanie wpływu poszczególnych zmiennych na dopasowanie modelu oraz analizę charakteru zależność (na przykład liniowa, nieliniowa) między predyktorami a wynikiem. 
wynikać z upowszechniania się rozwiązań, w których korzysta się z chmur obliczeniowych (Bisong, 2019). Jednocześnie na horyzoncie urzeczywistnia się perspektywa pojawienia się technologii, która może całkowicie zmienić oblicze informatyki, w tym algorytmów uczenia maszynowego - komputer kwantowy (Biamonte $\mathrm{i}$ in., 2017).

Szersze praktyczne zastosowanie algorytmów spowodowało rozwój samej metodologii uczenia maszynowego. Poza teoretykami zainteresowało ono szeroką rzeszę uczestników rynku, instytucji finansowych czy ośrodków edukacyjnych. W związku z tym można oczekiwać nie tylko kreowania nowych, doskonalszych narzędzi i technik, lecz również powszechniejszego wykorzystania znanych i praktykowanych już w wybranych obszarach metod badawczych.

\section{Zagrożenia}

Na tempo adaptacji metod ML do teorii i praktyki finansów mogą również w sposób niekorzystny wpływać pewne ograniczenia omawianych metod, jak i czynniki występujące w otoczeniu rynku kapitałowego. Problemem wynikającym z gruntu badań teoretycznych nad aplikowaniem uczenia maszynowego do zarządzania finansami jest fakt, że wspominana już stochastyczna natura algorytmów rodzi ryzyko kreowania fałszywych strategii inwestycyjnych, co może negatywnie wpływać na upowszechnianie strategii inwestycyjnych opartych na omawianych metodach. Badacze zajmujący się problematyką zastosowań metod opartych na uczeniu maszynowym mogą w praktyce przeprowadzać dużą liczbę symulacji wykorzystujących dane historyczne, ale publikować jedynie te cechujące się najlepszym wynikiem (de Prado, 2020). Tymczasem w rzeczywistości rosnąca liczba prowadzanych prób powinna odpowiednio wpływać na raportowane wyniki. $Z$ tej perspektywy im większy błąd oszacowania, tym większe potencjalne korzyści przy wyborze tylko najlepszych strategii i raportowaniu wyników, które nie są powtarzalne w praktyce.

Jak już wspomniano w zakresie omawiania słabości przedmiotowych metod, trenowanie algorytmów wymaga zasilania modeli dużymi zbiorami danych. Problemem jest dostęp do wykorzystywanych danych niezbędnych do tworzenia modeli dedykowanych analizie stóp zwrotu czy ryzyka instrumentów finansowych. Ograniczenia występują zarówno w obszarze podmiotowym (nie każdy uczestnik rynku może uzyskać dostęp do danych, na przykład z uwagi na wysoki koszt), jak i przedmiotowym (niektóre rodzaje informacji mogą być przekazywane do baz z opóźnieniem lub być w ogóle nieraportowane). Ponadto istniejące obecnie bazy w niepełnym zakresie dostarczają również danych o jakości zapewniającej optymalne warunki trenowania modeli.

Silną barierą rozwojową dla adaptacji innowacyjnych rozwiązań występującą w skali całego rynku finansowego jest wysoki poziom jego regulacji. 
Nieprzygotowane otoczenie regulacyjne często spowalnia transfer na rynek finansowy osiągnięć technologicznych czy modeli biznesowych wykorzystywanych w innych gałęziach gospodarki (Stradomski, 2007). Przykładowym obszarem zastosowań metod uczenia maszynowego, który doświadcza tego rodzaju problemów, jest robodoradztwo. W warstwie regulacyjnej toczy się obecnie dyskusja, czy podmioty działające na rynku robodoradztwa finansowego powinny podlegać takim samym regulacjom jak licencjonowani tradycyjni doradcy inwestycyjni. Takie stanowisko zajęła Komisja Nadzoru Finansowego, wskazując, że czynności polegające na uwzględniającym potrzeby i sytuację klienta przygotowaniu rekomendacji dotyczącej między innymi kupna lub sprzedaży instrumentów finansowych są doradztwem inwestycyjnym, a w efekcie stanowią działalność maklerską, której prowadzenie wymaga uzyskania odpowiedniej licencji (Rojszczak, 2020). Wskazany problem nie występuje jedynie w skali rynku polskiego - według danych z 2018 roku w żadnym państwie Unii Europejskiej nie prowadzono prac związanych z wprowadzeniem odrębnych regulacji dotyczących rynku robodoradztwa (Rojszak, 2020).

Najistotniejsze wnioski płynące z przeprowadzonej analizy SWOT potencjału wykorzystania metod uczenia maszynowego w procesie budowy portfela inwestycyjnego zostały usystematyzowane w tabeli 9.1 .

Tabela 9.1. Podsumowanie analizy SWOT stosowania uczenia maszynowego w procesie budowy portfela inwestycyjnego

\begin{tabular}{|c|c|}
\hline Mocne strony & Slabe strony \\
\hline $\begin{array}{l}\text { - możliwość prognozowania zmiennych obja- } \\
\text { śnianych na podstawie dużej niejednorodnej } \\
\text { bazy danych wejściowych } \\
\text { - zdolność identyfikowania nieliniowych za- } \\
\text { leżności zachodzących pomiędzy wieloma } \\
\text { zmiennymi objaśniającymi } \\
\text { - możliwość wytrenowania strategii inwesty- } \\
\text { cyjnej zoptymalizowanej pod kątem potrzeb } \\
\text { inwestora oraz specyficznych uwarunkowań } \\
\text { rynkowych } \\
\text { możliwość dostarczenia narzędzi do two- } \\
\text { rzenia strategii inwestycyjnych skuteczniej- } \\
\text { szych od inwestycji pasywnych }\end{array}$ & $\begin{array}{l}\text { - ograniczona możliwość projektowania na } \\
\text { podstawie danych historycznych strategii } \\
\text { inwestycyjnych optymalnych w warunkach } \\
\text { nieobserwowanych wcześniej zjawisk ryn- } \\
\text { kowych (na przykład kryzysów) } \\
\text { - trudność w doborze odpowiedniego szeregu } \\
\text { czasowego danych wejściowych do modelu } \\
\text { - zagrożenie przetrenowania oraz doboru } \\
\text { hiperparametrów } \\
\text { - stochastyczny charakter uczenia maszy- } \\
\text { nowego, który przekłada się na odmienne } \\
\text { wyniki prognoz zbudowanych na podstawie } \\
\text { kolejnych prób treningowych } \\
\text { - potrzeba budowy obszernych baz danych do } \\
\text { wyuczenia modeli } \\
\text { - potrzeba korzystania z potężnych mocy } \\
\text { obliczeniowych } \\
\text { - trudność w interpretacji wyników uzy- } \\
\text { skanych za pomocą modeli uczenia } \\
\text { maszynowego }\end{array}$ \\
\hline
\end{tabular}


Tabela $9.1-\mathrm{cd}$.

\begin{tabular}{|c|c|}
\hline Szanse & Zagrożenia \\
\hline $\begin{array}{l}\text { - rozwój technologii i wzrost mocy oblicze- } \\
\text { niowych komputerów wykorzystywanych do } \\
\text { tworzenia modeli } \\
\text { - rozwój dostępu do mocy obliczeniowych za } \\
\text { pomocą rozwiązań chmurowych } \\
\text { - perspektywy możliwości łatwiejszego i tań- } \\
\text { szego przechowywania zbiorów danych } \\
\text { - wzrost zainteresowania przedstawicieli prak- } \\
\text { tyki i nauki uczeniem maszynowym }\end{array}$ & $\begin{array}{l}\text { - możliwość selektywnego upowszechniania } \\
\text { strategii inwestycyjnych opartych na nierze- } \\
\text { telnie przeprowadzonych symulacjach } \\
\text { - ograniczenia w dostępności do baz zapew- } \\
\text { niających dane o odpowiedniej jakości nie- } \\
\text { zbędnej do prawidłowego uczenia modeli } \\
\text { - regulacje rynku finansowego niedostoso- } \\
\text { wane do pojawiających się innowacyjnych } \\
\text { rozwiązań opartych na algorytmach uczenia } \\
\text { maszynowego }\end{array}$ \\
\hline
\end{tabular}

Źródło: opracowanie własne.

\subsection{Przegląd badań na temat wykorzystania uczenia maszynowego w zarządzaniu portfelem inwestycyjnym}

\section{Wycena aktywów na rynkach kapitałowych}

Problematyka wyceny aktywów na rynkach kapitałowych jest skupiona wokół tezy, że na efektywnych rynkach finansowych wyższe oczekiwane zwroty stanowią rekompensatę za wyższe ryzyko systematyczne. Jednym z głównych celów empirycznej wyceny aktywów jest przewidywanie oczekiwanych stóp zwrotu. W zakresie przewidywania zwrotów z aktywów zapotrzebowanie odbiorców badań ogniskuje się na osiąganiu możliwie najdokładniejszych prognoz zwrotów na podstawie dostępnych informacji, jednak wnioskowanie o potencjalnych czynnikach, które je kształtują, analiza premii za ryzyko lub identyfikacja błędów w wycenie w konkretnych modelach czynnikowych stają się coraz istotniejsze z punktu widzenia zarówno teorii, jak i praktyki (Collot i Hemauer, 2021).

Standardowe procedury badawcze w empirycznej wycenie aktywów wiążą się ze zróżnicowanymi problemami, które są jednak wspólne dla wszystkich metod badawczych opartych na najpowszechniej wykorzystywanej w tym obszarze analizie regresji. Należy do nich w szczególności fakt, że niemożliwe jest uwzględnienie wszystkich możliwych predyktorów w standardowym modelu regresji liniowej bez narażania się na niebezpieczeństwo nadmiernego dopasowania modelu i współliniowości. Tymczasem w literaturze dotyczącej empirycznej wyceny aktywów badacze zidentyfikowali już setki czynników, które wykazują związek z wyższymi przyszłymi zwrotami (Harvey, Liu i Zhu (2016) wymieniają ponad 300 czynników, a Hou, Xue i Zhang (2020) ponad 450 czynników, które zostały zidentyfikowane jako potencjalnie wyjaśniające i przewidujące oczekiwane 
zwroty z akcji). Pominięcie więc któregokolwiek z nich przy badaniu znaczenia nowego czynnika, przy szacowaniu ładunków czynnikowych lub przy prognozowaniu oczekiwanych stóp zwrotu danych aktywów może prowadzić do pominięcia zmiennej, natomiast uwzględnienie ich wszystkich w modelu regresji doprowadzi do problemu nadmiernego dopasowania w próbie (Collot i Hemauer, 2021). Co więcej, pomimo tak znacznej liczby predyktorów stóp zwrotu sugerowanych w przeprowadzonych dotąd badaniach nadal mogą istnieć istotne czynniki, które nie zostały zidentyfikowane. W związku z tym, w celu neutralizacji błędu pominiętej zmiennej, nowe metody badawcze muszą, po pierwsze, w skuteczny sposób uwzględniać dotychczasowych stan wiedzy dzięki krytycznej analizie rozpoznanych dotąd czynników, a po drugie, muszą pozostawać otwarte na nowe czynniki, które nie zostały jeszcze rozpoznane w opublikowanych pracach. Metody uczenia maszynowego w pełni spełniają ten postulat.

Najbardziej przełomową pracą czerpiącą z możliwości uczenia maszynowego w tym obszarze jest badanie przeprowadzone przez Gu i in. (2020). Autorzy ci w szeroko zakrojonym badaniu obejmującym prawie 30 tys. akcji z rynku amerykańskiego w okresie 60 lat i biorącym pod uwagę 94 różne predyktory skonfrontowali z uogólnionymi modelami liniowymi takie metody uczenia maszynowego, jak techniki redukcji wymiarów, wzmocnione drzewa regresyjne, sieci neuronowe i losowe lasy decyzyjne. Odkryli, że narzędzia uczenia maszynowego poprawiają opis oczekiwanego zachowania zwrotu w porównaniu z tradycyjnymi metodami prognozowania. Jako metody o najlepszych wynikach wskazali lasy losowe i sieci neuronowe. Wszystkie przeanalizowane przez nich techniki uczenia maszynowego były zgodne co do niewielkiego zestawu dominujących sygnałów predykcyjnych obejmujących zmiany momentum, płynności i zmienności.

Wśród przeprowadzonych do tej pory badań relatywnie mała część prac skupiała się na połączeniu perspektywy analizy przekrojowej z analizą szeregów czasowych (Weigand, 2019). Interesujących wniosków na ten temat dostarczyło badanie Harveya i Liu (Harvey i in., 2016), którzy za pomocą procedury bootstrap zidentyfikowali predyktory nadające się do tłumaczenia oczekiwanych stóp zwrotów w obu tych perspektywach. Autorzy ci odkryli, że czynnik rynkowy jest czynnikiem dominującym, a drugi w kolejności pod względem istotności czynnik objaśniający stopy zwrotu wiąże się z rentownością. Praca Harveya i in. (2016) wytyczyła interesujący kierunek dla dalszych badań w obszarach, w których można napotkać problem wielokrotnych testów będących powszechną przeszkodą w wykorzystywaniu informacji typu big data, który został rozwinięty przez współautorów pracy: (Cong, Tang, Wang i Zhang, 2021). Autorom udało się zaimplementować oba wskazane podejścia jednocześnie do empirycznej wyceny aktywów.

Wskazując na właściwości metod uczenia maszynowego w zakresie badań nad empiryczną wyceną aktywów na rynkach kapitałowych, należy podkreślić ich zdolność do uzyskiwania dokładniejszych wniosków oraz neutralizowania wad metod 
stosowanych w tym obszarze wcześniej. Pomimo intensywnego już eksplorowania zastosowań algorytmów do analizy wycen aktywów na rynku kapitałowym w ostatnich latach istnieją jeszcze takie pola do zbadania, jak na przykład analiza zmienności poziomu premii za ryzyko w perspektywie przekrojowej i szeregów czasowej.

\section{Optymalizacja składu portfela inwestycyjnego}

Problem wyboru portfela inwestycyjnego stanowi jeden z najdogłębniej badanych obszarów finansów od czasu zaproponowania przez Markowitza w 1952 roku (Markowitz, 1952) mechanizmu optymalizacji portfela w drodze minimalizowania jego wariancji, określanego mianem „nowoczesnej teorii portfelowej”. Ta przełomowa praca $\mathrm{w}$ dziedzinie finansów dała asumpt do setek kolejnych badań, których intencją było zaproponowanie sposobu optymalizacji portfela o bardziej praktycznym charakterze (Kaczmarek i Perez, 2021). W szczególności krytyka teorii portfela dotyczy problemu wysokiej wrażliwości wyników optymalizacji na zmiany danych wejściowych, co skutkuje niestabilnymi lub nieintuicyjnymi wynikami (Kolm, Tütüncü i Fabozzi, 2014).

Literatura wskazuje na kilka głównych kierunków usprawnień ram optymalizacji portfela. Pierwszym z nich jest odejście od wykorzystywania statystycznych momentów zwrotu aktywów w kierunku bardziej wiarygodnych prognoz wspartych przekrojowymi charakterystykami danych aktywów (DeMiguel, Garlappi i Uppal, 2009). Drugi to przejście od optymalizacji kwadratowej do kryteriów dominujących we współczesnej matematyce, w tym teorii grafów i uczenia maszynowego. Technika optymalizacji hierarchicznego parytetu ryzyka (HRP) zaproponowana przez Lopeza de Prado (López de Prado, 2016) zastępuje macierz kowariancji stosowaną przez optymalizatory kwadratowe strukturą drzew, zwiększając stabilność wag. Eksperymenty Monte Carlo pokazują, że HRP zapewnia niższą wariancję poza próbą niż algorytm linii krytycznej Markowitza (Kaczmarek i Perez, 2021).

Metody uczenia maszynowego przyczyniły się do uzupełniania teoretycznego podejścia proponowanego przez teorię portfela o wymiar praktyczny. Dzięki podejściu opartemu na „uczących się” algorytmach możliwe jest formułowanie strategii inwestycyjnych, których założenia na bieżąco są dostosowywane do zmieniających się warunków otoczenia, przez co dynamicznie dostosowywane są założenia dotyczące kryteriów, względem których następuje optymalizacja.

\section{Zarządzenie ryzykiem portfela inwestycyjnego, w tym ryzykiem obsunięcia kapitału}

Najczęściej wykorzystywaną w praktyce gospodarczej miarą oceny efektywności portfela inwestycyjnego jest wskaźnik Sharpe'a oraz jego odmiany. Niestety, posiada on pewne wady, które sprawiają, że nie jest w pełni dostosowany do potrzeb 
inwestorów giełdowych. Wskaźnik Sharpe’a mierzy efektywność portfela jako relacje pomiędzy jego stopą zwrotu oraz ryzykiem, definiowanym jako odchylenie standardowe. Tymczasem odchylenie standardowe stóp zwrotu z portfela wskazuje jedynie na średni dystans pomiędzy poszczególnymi stopami zwrotu a ich wartością średnią w danym okresie. Jednakże miarą ryzyka portfela, która najbardziej interesuje typowego inwestora, jest obsunięcie kapitału, a w szczególności najwyższe obniżenie kapitału podczas trwania całego okresu inwestycji. Indykatorem służącym do oceny tego ryzyka jest maksymalne zmniejszenie kapitału (maximum drawdown) (Möller, 2018) wykorzystywane do oceny efektywności portfela inwestycyjnego w ramach wskaźnika Calmara (Magdon-Ismail i Atiya, 2004).

Typowym podejściem wykorzystywanym do kontroli ryzyka portfela inwestycyjnego jest dywersyfikacja. Podział aktywów w portfelu może dotyczyć instrumentów z tej samej klasy aktywów bądź z różnych klas. Dywersyfikacja jest bardzo skutecznym narzędziem służącym do eliminacji ryzyka niesystematycznego związanego z pojedynczymi elementami składowymi portfela. Historycznie wykazywała również wysoką skuteczność w zakresie kontroli ryzyka zmienności poprzez stały podział inwestycji na część akcyjną oraz dłużną. Dodanie instrumentów dłużnych do portfela zwiększało jego efektywność. Efekt ten był pochodną ujemnej korelacji pomiędzy instrumentami akcyjnymi i dłużnymi. Ponadto stabilny dochód z obligacji skarbowych pozwalał uzyskiwać stopę zwrotu przewyższającą poziom inflacji. Niestety, ta relacja przestała działać. Dziś rentowność obligacji skarbowych z rynków rozwiniętych jest bardzo niska i nie przekracza poziomu inflacji. Można przypuszczać, że negatywne realne stopy procentowe przyczynią się w dłuższym terminie do wzrostu poziomu stóp procentowych, co w efekcie wywoła spadek cen obligacji skarbowych. Nie jest to sprzyjające środowisko do ograniczania ryzyka inwestycyjnego portfela poprzez utrzymywanie stałej ekspozycji w obligacjach skarbowych.

W sytuacji gdy potrzeby inwestorów w zakresie kontroli ryzyka są odmienne od powszechnie stosowanych środków, a tradycyjne mechanizmy kontroli ryzyka inwestycyjnego portfela są mniej skuteczne, warto poszukiwać nowej możliwości. Odpowiedzią na to wyzwanie są metody uczenia maszynowego, które dostarczają narzędzi do budowy strategii inwestycyjnych ukierunkowanych na zarządzanie ryzykiem inwestycyjnym portfela. Poniżej zaprezentowano dwa podejścia stosowane w literaturze, które stanowią jedynie zarys wszystkich możliwości oferowanych przez uczenie maszynowe.

Pierwszą $z$ nich jest zastosowanie uczenia przez wzmacnianie jako narzędzia służącego do budowy strategii inwestycyjnej. Mocną stroną tej metody jest możliwość zdefiniowania funkcji celu ukierunkowanej na ograniczenie ryzyka obsunięcia kapitału. Skuteczność takiego podejścia prezentują Almahdi oraz Yang (2017), którzy jako funkcję celu określają bezpośrednio wskaźnik Calmara. W swoim badaniu wykazują, że wykorzystanie uczenia przez wzmacnianie ukierunkowanego 
na maksymalizację wskaźnika Calmara skuteczniej kontroluje ryzyko zmniejszenia kapitału w porównaniu do innych, tradycyjnych metod opartych na dywersyfikacji portfela.

Inną metodą służącą do kontroli ryzyka inwestycyjnego portfela jest strategia docelowej zmienności. Jej idea polega na dynamicznym dostosowywaniu poziomu alokacji portfela w jego części udziałowej na podstawie prognozowanego poziomu zmienności rynków akcyjnych (Perchet, de Carvalho, Heckel i Moulin, 2015). Kluczowym wyzwaniem w stosowaniu tej metody jest skuteczne prognozowanie przyszłego poziomu zmienności rynków akcyjnych. Ciekawym narzędziem, które może zostać wykorzystane do rozwiązania tego problemu, są rekurencyjne sieci neuronowe. Prognozy zmienności oparte na rekurencyjnych sieciach neuronowych pozwalają na budowę strategii docelowej zmienności portfela, która charakteryzuje się wyższymi wskaźnikami Sharpe’a i Calmara w porównaniu do odpowiednich indeksów rynkowych (Kaczmarek i in., 2021; Kim i Won, 2018).

Podsumowując, uczenie maszynowe dostarcza wartościowych narzędzi służących do kontroli ryzyka inwestycyjnego portfela. Rozwiązania te dają odpowiedź na potrzeby inwestorów związane z kontrolą ryzyka wyrażonego jako maksymalne obsunięcie kapitału. Ponadto oferują alternatywne do dywersyfikacji rozwiązania do zarządzania poziomem zmienności inwestycji.

\subsection{Podsumowanie}

Intencją autorów tego rozdziału było przybliżenie dotychczasowych osiągnięć w zakresie optymalizacji składu portfela inwestycyjnego oraz wskazanie perspektyw i możliwych kierunków dalszego rozwoju tej dziedziny z wykorzystaniem potencjału, jaki stwarza uczenie maszynowe. Potencjał omawianych metod jest kształtowany głównie przez mocne strony metod ML, wśród których należy podkreślić zdolność do prognozowania zmiennych objaśnianych na podstawie dużej liczby niejednorodnych danych wejściowych; zdolność do wychwytywania nieliniowych relacji pomiędzy wieloma zmiennymi objaśniającymi; zdolność do wytrenowania strategii inwestycyjnej zoptymalizowanej pod kątem potrzeb inwestora oraz specyficznych uwarunkowań rynkowych (za pomocą uczenia przez wzmocnienie) czy wreszcie możliwość dostarczenia narzędzia do tworzenia strategii inwestycyjnych skuteczniejszych od inwestycji pasywnych. Rozwój algorytmów w najbliższym czasie może być uzależniony w szczególności od udoskonalenia obszarów, w których metody te wykazują obecnie pewne słabości. Należą do nich: ryzyko przetrenowania; problematyka doboru hiperparametrów; stochastyczna natura powodująca, że wagi poszczególnych prób treningowych są inicjowane w sposób losowy, co owocuje odmiennymi wynikami końcowymi wyuczonych modeli; potrzeba budowy obszernych baz danych, które mogą służyć 
do wyuczenia modeli; potrzeba potężnych mocy obliczeniowych wymaganych do trenowania wybranych modeli czy trudność w interpretowaniu wyników generowanych przez dużą część modeli uczenia maszynowego.

Jak przedstawiono $\mathrm{w}$ przeglądzie badań odnoszących się do wykorzystania algorytmów uczenia maszynowego w zarządzaniu portfelem inwestycyjnym, implementacja nowoczesnych metod badawczych może stanowić twórcze rozwinięcie potrzeb i rozwiązanie problemów stojących zarówno przed badaczami nauki finansów, jak i praktykami rynku finansowego.

\section{Bibliografia}

Almahdi, S. i Yang, S. Y. (2017). An adaptive portfolio trading system: A risk-return portfolio optimization using recurrent reinforcement learning with expected maximum drawdown. Expert Systems with Applications, 87, 267-279. https://doi.org/10.1016/j. eswa.2017.06.023

Barto, A. G. i Dietterich, T. G. (2004). Reinforcement learning and its relationship to supervised learning. Handbook of Learning and Approximate Dynamic Programming, 10, 9780470544785.

Biamonte, J., Wittek, P., Pancotti, N., Rebentrost, P., Wiebe, N. i Lloyd, S. (2017). Quantum machine learning. Nature, 549(7671), 195-202.

Bisong, E. (2019). Google cloud machine learning engine (Cloud MLE). W: Building machine learning and deep learning models on Google cloud platform (s. 545-579). Springer.

Cochrane, J. H. (2011). Presidential address: Discount rates. Journal of Finance, 66(4), 1047-1108. https://doi.org/10.1111/j.1540-6261.2011.01671.x

Collot, S. i Hemauer, T. (2021). A literature review of new methods in empirical asset pricing : omitted-variable and errors-in-variable bias. Financial Markets and Portfolio Management, 35(1), 77-100. https://doi.org/10.1007/s11408-020-00358-0

Cong, L. W., Tang, K., Wang, J. i Zhang, Y. (2021). Deep sequence modeling: Development and applications in asset pricing. The Journal of Financial Data Science, 3(1), 28 LP - 42. https://doi.org/10.3905/jfds.2020.1.053

DeMiguel, V., Garlappi, L. i Uppal, R. (2009). Optimal versus naive diversification: How inefficient is the 1/N portfolio strategy? The Review of Financial Studies, 22(5), 19151953. https://doi.org/10.1093/rfs/hhm075

Fischer, T. (2018). Reinforcement learning in financial markets - a survey. FAU Discussion Papers in Economics.

Freyberger, J., Neuhierl, A. i Weber, M. (2020). Dissecting characteristics nonparametrically. The Review of Financial Studies, 33(5), 2326-2377. https://doi.org/10.1093/ $\mathrm{rfs} / \mathrm{hhz} 123$

Géron, A. (2019). Hands-on machine learning with scikit-learn, keras, and tensorflow: Concepts, tools, and techniques to build intelligent systems. O'Reilly Media, Incorporated. 
Greenwell, B. M., Boehmke, B. C. i Mccarthy, A. J. (2018, 12 May). A simple and effective model-based variable importance measure arXiv : 1805 . 04755v1 [stat. ML].

Groth, S. S. i Muntermann, J. (2011). An intraday market risk management approach based on textual analysis. Decision Support Systems, 50(4), 680-691. https://doi.org/10.1016/j.dss.2010.08.019

Gu, S., Kelly, B. i Xiu, D. (2020). Empirical asset pricing via machine learning. Review of Financial Studies, 33(5), 2223-2273. https://doi.org/10.1093/rfs/hhaa009

Harvey, C. R., Liu, Y. i Zhu, H. (2016). ... and the cross-section of expected returns. The Review of Financial Studies, 29(1), 5-68. https://doi.org/10.1093/rfs/hhv059

Hou, K., Xue, C. i Zhang, L. (2020). Replicating anomalies. The Review of Financial Studies, 33(5), 2019-2133. https://doi.org/10.1093/rfs/hhy131

Kaczmarek, T., Bedowska-Sojka, B., Grobelny, P. i Perez, K. (2021). False safe haven assets: Evidence from the target volatility strategy based on recurrent neural network. SSRN Electronic Journal. https://doi.org/10.2139/ssrn.3780149

Kaczmarek, T. i Perez, K. (2021). Building portfolios based on machine learning predictions. Economic Research-Ekonomska Istraživanja, 1-19. https://doi.org/10.1080/ $1331677 \mathrm{x} .2021 .1875865$

Kim, H. Y. i Won, C. H. (2018). Forecasting the volatility of stock price index: A hybrid model integrating LSTM with multiple GARCH-type models. Expert Systems with Applications, 103, 25-37. https://doi.org/10.1016/j.eswa.2018.03.002

Koller, D. i Fratkina, R. (1998). Using learning for approximation in stochastic processes. ICML, 287-295.

Kolm, P. N., Tütüncü, R. i Fabozzi, F. J. (2014). 60 Years of portfolio optimization: Practical challenges and current trends. European Journal of Operational Research, 234(2), 356-371. https://doi.org/10.1016/j.ejor.2013.10.060

Li, Y., Turkington, D. i Yazdani, A. (2020). Beyond the black box: An intuitive approach to investment prediction with machine learning. The Journal of Financial Data Science, 2(1), 61-75. https://doi.org/10.3905/jfds.2019.1.023

López de Prado, M. (2016). Building diversified portfolios that outperform out of sample. Journal of Portfolio Management, 42(4), 59-69. https://doi.org/10.3905/ jpm.2016.42.4.059

Magdon-Ismail, M. i Atiya, A. F. (2004). Maximum drawdown. Risk Magazine, 17(10), 99-102.

Markowitz, H. (1952). Portfolio selection. The Journal of Finance, 7(1), 77-91. https:// doi.org/10.2307/2975974

MÖLLER, P. M. (2018). Drawdown measures and return moments. International Journal of Theoretical and Applied Finance, 21(07), 1850042. https://doi.org/10.1142/ S0219024918500425

Molnar, C. (2020). Interpretable machine learning. A guide for making black box models Explainable. Pobrane z https://christophm.github.io/

Obaid, K. i Pukthuanthong, K. (2018). A picture is worth a thousand words: Market sentiment from photos. SSRN Electronic Journal. https://doi.org/10.2139/ssrn.3297930

Paliński, A. (2018). Metody uczenia maszynowego w prognozowaniu niewypłacalności. Studia Ekonomiczne. Zeszyty Naukowe Uniwersytetu Ekonomicznego w Katowicach, 358, 173-181. 
Perchet, R., de Carvalho, R. L., Heckel, T. i Moulin, P. (2015). Predicting the success of volatility targeting strategies: Application to equities and other asset classes. The Journal of Alternative Investments, 18(3), 21-38. https://doi.org/10.3905/jai.2016.18.3.021 de Prado, M. L. (2018). Advances in financial machine learning. John Wiley \& Sons.

de Prado, M. L. (2020). Machine learning for asset managers. Cambridge University Press.

Rojszczak, M. (2020). Sztuczna inteligencja w innowacjach finansowych - aspekty prawne i regulacyjne. Internetowy Kwartalnik Antymonopolowy i Regulacyjny, 2(9), 61-77. https://doi.org/10.7172/2299-5749.IKAR.2.9.5

Schlegel, D. (2015). Deep machine learning on Gpu. University of Heidelber-Ziti, 12.

Snihovyi, O., Kobets, V. i Ivanov, O. (2019). Implementation of robo-advisor services for different risk attitude investment decisions using machine learning techniques. Springer International Publishing. https://doi.org/10.1007/978-3-030-13929-2

Stradomski, M. (2007). Wykorzystanie innowacji finansowych w warunkach niedoskonałego rynku finansowego. Zeszyty Naukowe Uniwersytetu Szczecińskiego. Finanse, Rynki Finansowe, Ubezpieczenia, 6, Cz. II. Rynek kapitałowy: skuteczne inwestowanie, 433-446.

Sutton, R. S. i Barto, A. G. (1998, grudzień). Reinforcement learning : an introduction. MIT Press.

Waliszewski, K. (2020). Robo-doradztwo jako przykład fin-techu - problem regulacji i funkcjonowania. Przeglad Ustawodawstwa Gospodarczego, 7, 12-20. https://doi. org/10.33226/0137-5490.2020.7.2

Weigand, A. (2019). Machine learning in empirical asset pricing. Financial Markets and Portfolio Management, 33(1), 93-104. https://doi.org/10.1007/s11408-019-00326-3

Welch, I. i Goyal, A. (2007). A comprehensive look at the empirical performance of equity premium rediction. The Review of Financial Studies, 21(4), 1455-1508. https://doi. org/10.1093/rfs/hhm014

Yates, R. D. i Goodman, D. J. (2014). Probability and stochastic processes: a friendly introduction for electrical and computer engineers. John Wiley \& Sons. 